\title{
End-of-life decisions. Recent jurisprudence of the European Court of Human Rights
}

\author{
Arend Cornelis Hendriks ${ }^{1}$
}

Published online: 19 September 2018

(C) The Author(s) 2018

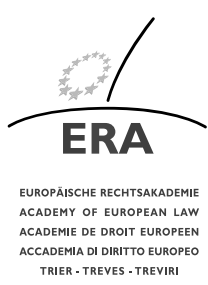

Abstract The European Convention on Human Rights as well as the Biomedicine Convention do not give instructions to States on how to regulate end-of-life issues, such as euthanasia and physician assisted dying. The right to life suggests that States should above all protect human life and take steps in case this entitlement is violated. Over the course of the last years, the European Court of Human Rights has acknowledged that individuals also have a right to personal autonomy. Persons who are mentally competent to make informed decisions can, according to the European Court, decide to refuse treatment and, under certain circumstances, decide to shorten their life, depending on the domestic legal framework. States are left a large margin of appreciation to regulate end-of-life issues. Besides these self-chosen exceptions, doctors may come to the conclusion that further artificial nutrition, hydrating or life sustaining treatment is not justified, provided that such decisions are taken in an utterly careful way and in accordance with domestic legislation.

Keywords End-of-life · Human rights · Biomedicine · Right to life · Autonomy · Right to private life

\section{Introduction}

In 2017 the Convention on Human Rights and Biomedicine existed 20 years. This Convention, also called the Biomedicine Convention or Oviedo Convention, is a legally binding instrument on the protection of human rights in the biomedical field. The very existence of this Council of Europe convention reflects the need to clarify and where necessary expand the human rights protected by the European Convention

$\square$ A.C. Hendriks

a.c.hendriks@law.leidenuniv.nl

1 Professor in Health Law, Leiden University, Leiden, Netherlands 
on Human Rights (ECHR). The latter convention, also drafted within the context of the Council of Europe, was adopted in 1950, largely influenced by the atrocities committed in the Second World War. The ECHR was not particularly focused on existing, let alone future biomedical issues, such as organ donation, research with human beings, genetic testing and human cloning. These and other issues are covered, or at least elaborated upon, in the Biomedicine Convention or one of its protocols.

Like the ECHR, the Biomedicine Convention fails to address the issue of euthanasia and other end-of-life issues. This may come as a surprise given the heated debates on these issues in various European-and non-European-countries. ${ }^{1}$ Thanks to better socio-economic conditions and improved health care the life expectancy of Europeans has spectacularly improved. Nowadays almost 20 per cent of the Europeans is aged 65 or more. For a substantial group of these persons-as well as younger persons - life is not always the highest attainable value that should be protected by all means. This reflects the importance that is increasingly being attached to personal autonomy and self-determination when it comes to end-of-life decisions. In many countries these developments have resulted in laws on-how it is sometimes called-dying with dignity. In fact, some European States have legalised, or at least decriminalised, euthanasia and physician assisted dying (Belgium, Luxembourg and the Netherlands) and many more States allow individuals to refuse treatment, to order a lethal drug or to otherwise deliberately shorten their life (e.g. France, Germany, Spain and Switzerland).

As with the adoption of these domestic laws, the regulation of these forms of treatment is utterly difficult on a European level, if not impossible, given the variety of cultures and legal traditions. Medical associations also disagree on the issue whether physicians can, under certain circumstances, be involved in end-of-life issues. ${ }^{2}$ This explains why there is no consensus between the Member States of the Council of Europe on this issue, making it difficult for European Court of Human Rights (ECtHR) to impose its own view on end-of-life cases.

The latter has not inhibited individual applicants to ask judgments of the ECtHR on end-of-life questions. In fact, there seems to be an increasing number of cases on which the ECtHR is requested to decide on shortening or prolonging the life of individuals in various situations. In these cases the ECtHR traditionally seeks to balance the entitlements laid down in, on the one hand, the right to life (Article 2 ECHR) and, in the other hand, the right to private life (Article 8 ECHR). Implicitly, the ECtHR also builds on the Biomedicine Convention, particularly the provisions on informed consent (Articles 5-9).

In this contribution I will review how the case law of the ECtHR has developed over the course of years, when interpreting the right to life and the right to private life. I will confine myself to studying the end-of-life cases that emerged in the health care sector, thus not speak about people who threaten to commit suicide because of the length of their imprisonment, the prison conditions or the threat of a possible expulsion. This implies that I will only articulate the prohibition or permissibility of endof-life decisions with the involvement of a physician or other health care provider. In

\footnotetext{
${ }^{1}$ Negri [1].

${ }^{2}$ So far the World Medical Association (WMA) holds the view euthanasia is in conflict with basic ethical principles of medical practice WMA Resolution on Euthanasia (2013).
} 
doing so I will also analyse in which end-of-life cases the ECtHR has referred to the Biomedicine Convention.

\section{The right to life}

The right to life is the very first material provision of the ECHR. According to Article 2 ECHR 'Everyone's right to life shall be protected by law. No one shall be deprived of his life intentionally save in the execution of a sentence of a court following his conviction of a crime for which this penalty is provided by law'. Since the adoption of the ECHR, the Council of Europe has abolished the death penalty (Protocol No. 6 and Protocol No. 13), so that the latter exception can no longer be applied by Member States of the Council of Europe.

The ECtHR generally considers the right to life to be 'one of the most fundamental provisions in the Convention.' ${ }^{3}$ Or, as the Court emphasised in another decision, Article 2 is a provision 'from which no derogation is permitted' enshrining 'one of the basic values of the democratic societies making up the Council of Europe'. ${ }^{4}$ For Member States of the Council of Europe this right notably implies a prohibition (negative obligation) to deliberately take the life of individuals. But, according to the case law of the ECtHR, the right to life also enshrines positive obligations for national authorities, notably the duty to take appropriate steps to safeguard the lives of those within its jurisdiction. ${ }^{5}$ Subsequently, Member States are required to make regulations compelling hospitals, whether public or private, to adopt appropriate measures for the protection of their patients' lives and to ensure that those responsible for the death of patients in the care of the medical profession, whether in the public or the private sector, can be made accountable. ${ }^{6}$ This duty also obligates Member States to foresee a form of effective official investigation into death cases when there is doubt about the precise cause of death, notably when death has been caused by a criminal act. ${ }^{7}$ The latter is not to suggest that all death cases in hospitals are attributable to the intentional failure by members of the medical staff to comply with Article 2 ECHR. The ECtHR recently emphasised the duty of Member States to adopt appropriate measures for the protection of patients' lives in the health care sector, that is to say to have an adequate regulatory framework that is also enforced. Even in case of death or personal injury due to medical negligence in the health care sector, this does not necessarily constitute a violation of Article 2 ECHR, let alone an obligation to

\footnotetext{
${ }^{3}$ McCann et al. v. the UK (GC), no. 18984/91, 27 September 1995, ECLI:CE:ECHR:1995:0927JUD 001898491 , para. 147.

${ }^{4}$ Makaratzis v. Greece (GC), no. 50385/99, 20 December 2004, ECLI:CE:ECHR:2004:1220JUD00503 8599, para. 56.

${ }^{5}$ Guerra et all v. Italy, no. 14967/89, 19 February 1998, ECLI:CE:ECHR:1998:0219JUD001496789, para. 58 and ECtHR 9 June 1998, L.C.B. v. the UK, no. 23413/94, ECLI:CE:ECHR:1998:0609JUD002341394, para. 36 .

${ }^{6}$ Calvelli and Ciglio t. Italy (GC), no. 32967/96, 17 January 2002, ECLI:CE:ECHR:2002:0117JUD 003296796, para. 49.
}

${ }^{7}$ Kaya v. Turkey, no. 22729/93, 19 February 1998, ECLI:CE:ECHR:1998:0219JUD002272993, para. 86. 
require the provision of a criminal-law remedy, ${ }^{8}$ unless a patient was denied medical treatment. $^{9}$

To summarise, Article 2 imposes a number of negative and positive obligations on Member States, to protect the life of individuals and to take measures in case individuals die due to situations that could have been prevented. The Member State is accountable for compliance with the right to life. In order to comply with this obligation the Member State is also required to ensure that hospitals and others who provide health care are bound by regulations to protect the lives of individuals.

\section{Private life and autonomy}

While the right to life is, under the ECHR and the case law of the ECtHR, mainly seen as a provision that requires Member States to act or refrain from action to protect life, the right to private and family life is increasingly perceived as an entitlement to personal autonomy. With respect to health care, the ECtHR referred for the first time to 'personal autonomy' in the case of Pretty. ${ }^{10}$ The ECtHR held here that the notion of personal autonomy is an important principle underlying the interpretation of the Convention's guarantees. ${ }^{11}$ In the case of Pretty and subsequent cases, the ECtHR spoke about the 'notion of personal autonomy'. ${ }^{12}$ Since 2006 the ECtHR considers personal autonomy to constitute a 'right'. ${ }^{13}$ Personal autonomy notably seeks to guarantee the right to be free to exercise one's rights and freedoms the way one wants. With respect to health care, this right usually requires that physicians and other health care providers first of all provide adequate information on the possible forms of treatment before an individual can give his or her informed consent. ${ }^{14}$ In the before mentioned case of Pretty, the ECtHR held that 'the imposition of medical treatment, without the consent of a mentally competent adult patient, would interfere with a person's physical integrity in a manner capable of engaging the rights protected under Article $8 \S 1$ of the Convention. ${ }^{15}$ In other words, a person can only make

\footnotetext{
${ }^{8}$ Mastromatteo v. Italy (GC), no. 37703/97, 24 October 2002, ECLI:CE:ECHR:2002:1024JUD00377039, para. 90 and Silih v. Slovenia (GC), no. 71463/01, 9 April 2009, ECLI:CE:ECHR:2009:0409JUD 007146301 , para. 192.

${ }^{9}$ Lopes de Sousa Fernandes v. Portugal (GC), no. 56080/13, 19 December 2017, ECLI:CE:ECHR:2017: 1219JUD005608013 and Sarishvili-Bolkvadze v. Georgia, no. 58240/08, 19 July 2018, ECLI:CE:ECHR: 2018:0719JUD005824008.

${ }^{10}$ Pretty v. the UK, no. 2346/02, 29 April 2002, ECLI:CE:ECHR:2002:0429JUD000234602.

${ }^{11}$ Idem, para. 61.

${ }^{12}$ See e.g. Christine Goodwin v. the UK (GC), no. 28957/95, 11 July 2002, ECLI:CE:ECHR:2002: 0711JUD002895795, para. 89 and K.A. and A.D. t. Belgium, nos. 42758/98 and 45558/99, 17 February 2005, ECLI:CE:ECHR:2005:0217JUD004275898, para. 83.

${ }^{13}$ Evans v. the UK, no. 6339/05, 7 March 2006, ECLI:CE:ECHR:2006:0307JUD000633905, para. 57.

${ }^{14}$ Trocellier v. France (dec.), no. 75725/01, 5 October 2006, ECLI:CE:ECHR:2006:1005DEC007572501 and Glass v. the UK, no. 61827/00, 9 March 2004, ECLI:CE:ECHR:2004:0309JUD006182700.

${ }^{15}$ Pretty v. the UK, no. 2346/02, 29 April 2002, ECLI:CE:ECHR:2002:0429JUD000234602, para. 63. See also Codarcea v. Romania, no. 31675/04, 2 June 2009, ECLI:CE:ECHR:2009:0602JUD003167504, para. 104; V.C. v. Slovakia, no. 18968/07, 8 November 2011, ECLI:CE:ECHR:2011:1108JUD00189680 and G.B. and R.B. v. Moldova, no. 16761/09, 18 December 2012, ECLI:CE:ECHR:2012:1218JUD001676109.
} 
use of his or her personal autonomy with respect to medical interventions after he or she has given informed consent. According to the ECtHR, Member States are bound to adopt the necessary regulatory measures to ensure that doctors consider the foreseeable consequences of a planned medical procedure on their patients' physical integrity and to inform patients of these consequences beforehand in such a way that the latter are able to give informed consent. ${ }^{16}$ The failure to provide the necessary information to the patient and get his or her consent may not merely lead to a violation of Article 8 ECHR but also constitute a violation of Article 3 ECHR (prohibition of torture). ${ }^{17}$ This generally requires that the person concerned is mentally competent to make an informed decision, if not that he or she has a legal representative who acts in his best interests, ${ }^{18}$ and the absence of an emergency situation when health care providers should act in accordance with their professional standard to protect the life and well-being of the individual concerned.

In short, the ECtHR considers the right to personal autonomy and the right to informed consent to be important preconditions to make use of the right to private life and other rights related to health care protected by the ECHR. In fact, if patients are treated without their informed consent this may lead to direct liability of the Member State concerned. ${ }^{19}$ Informed consent is not only a prerequisite for a medical intervention, but mentally competent individuals can also decide to refuse to consent to treatment even if this may lead to a fatal outcome. ${ }^{20}$

\section{Recent decisions and judgments on end-of-life cases}

From the above it follows that Article 2 and Article 8 ECHR impose different obligations on Member States of the Council of Europe, duties that may point into different directions. Even though the ECtHR acknowledges that mentally competent individuals may decide to refuse potentially life-saving treatment, it is not clear to what extent Article 2 and Article 8 permit, or decline, individuals to ask physicians or other health care providers to assist them in ending their life.

The earlier mentioned Pretty case was the first decision of the ECtHR on an endof-life case, even though the applicant did not ask for the assistance of a health care provider to assist her in ending her life. The applicant in this case was a 43-year-old woman who suffered from a form of motor neurone disease (MND). MND is a progressive neuro-degenerative disease of motor cells within the central nervous system

\footnotetext{
${ }^{16}$ Csoma v. Romania, no. 8759/05, 15 January 2013, ECLI:CE:ECHR:2013:0115JUD000875905, para. 42.

${ }^{17}$ Yazgül Yilmaz v. Turkey, no. 36369/06, 1 February 2011, ECLI:CE:ECHR:2011:0201JUD003636906 and I.G. et all v. Slovakia, no. 15966/04, 13 November 2012, ECLI:CE:ECHR:2012:1113JUD001596604.

${ }^{18}$ Sommerfeld v. Germany (GC), no. 31871/96, 8 July 2003, ECLI:CE:ECHR:2003:0708JUD003187196, para. 62.

${ }^{19}$ Csoma v. Romania, no. 8759/05, 15 January 2013, ECLI:CE:ECHR:2013:0115JUD000875905, para. 42.

${ }^{20}$ Pretty v. the UK, no. 2346/02, 29 April 2002, ECLI:CE:ECHR:2002:0429JUD000234602, para. 63 and Jehovah's Witnesses of Moscow et all v. Russia, no. 302/02, 10 June 2010, ECLI:CE:ECHR:2010: 0610JUD000030202, para. 135.
} 
which will eventually result in the death of the person concerned due to progressive muscle weakness involved. There is no cure for MND and treatment will only slightly alter the course of this disease. In the case of the applicant, the disease had rapidly advanced and her health had significantly deteriorated. The applicant's life expectancy was poor. She was very concerned about the further course of the disease and strongly wanted to be able to control how and when she would die. She thereto wished to commit suicide, an act not prohibited under English law. Her disease did, however, not allow her to do so without the assistance of another person. According to English law, assisting another person to commit suicide was however prohibited. Since the applicant wanted her husband to help her to commit suicide, she asked the Director of Public Prosecutions to give an undertaking not to prosecute the applicant's husband should he assist her to commit suicide in accordance with her wishes. This request for immunity was, however, rejected.

The ECtHR emphasised, in its judgment on this case, the importance of the notion of personal autonomy as a principle underlying the interpretation of the guarantees of the Convention. ${ }^{21}$ At the same time, however, the ECtHR held that 'Article 2 cannot, without a distortion of language, be interpreted as conferring the diametrically opposite right, namely the right to die; nor can it create a right to self-determination in the sense of conferring on an individual the entitlement to choose death rather than life. ${ }^{22}$ The ECtHR eventually decided that the UK authorities had not violated Article 2, Article 8 or any of the other Articles invoked by the applicant.

While the ECtHR thus decided that the ECHR does not contain a right to die, this does not mean that the ECtHR radically opposes States to allow individuals to decide for themselves how and when they would like to end their life. This follows from the case of Haas versus Switzerland. ${ }^{23}$ This case concerned a man with a serious bipolar affective disorder, who had twice attempted to commit suicide and who had stayed in psychiatric hospitals on several occasions. The applicant had asked several psychiatrists to obtain 15 grams of sodium pentobarbital, which is available only on prescription in Switzerland, to end his life. All psychiatrists had, however, refused to do so. According to the applicant, the requirement to need a prescription violated his right of choosing the time and manner of his death, and thus of Article 8 ECHR. The ECtHR explicitly acknowledged 'that an individual's right to decide by what means and at what point his or her life will end, provided he or she is capable of freely reaching a decision on this question and acting in consequence, is one of the aspects of the right to respect for private life within the meaning of Article 8 of the Convention.' ${ }^{24}$ However, despite the fact that the ECtHR allows Member States, while granting them a large margin of appreciation, to give individuals an important say in end-of-life decisions, the ECtHR shared the view of the Swiss Federal Court that the right to life obliges States to establish a procedure capable of ensuring that a decision to end one's life does correspond to the free will of the individual concerned. According to the ECtHR, the requirement for a medical prescription for a lethal dose

\footnotetext{
${ }^{21}$ Pretty v. the UK, no. 2346/02, 29 April 2002, ECLI:CE:ECHR:2002:0429JUD000234602, para. 61.

${ }^{22}$ Idem, para. 39.

${ }^{23}$ Haas v. Switzerland, no. 31322/07, 20 January 2011, ECLI:CE:ECHR:2011:0120JUD003132207.

${ }^{24}$ Idem, para. 51.
} 
of sodium pentobarbital is a means enabling this obligation to be met. Consequently, Article 8 ECHR was not violated.

The case Gross versus Switzerland also concerned the denied access to a lethal dose of a drug to end the life of the applicant. ${ }^{25}$ Different from in the case of Haas, the applicant in Gross, an elderly woman, was not suffering from a clinical disease. As a result of the absence of a medically classified disease, the doctors had refused to give her a prescription to end her life. The applicant held that the Swiss authorities had breached Article 8 ECHR by not giving her access to a lethal dose of a drug. A majority of a Chamber concluded that there had been a violation of Article 8 ECHR. The Chamber particularly found that Swiss law was not clear enough as to when assisted suicide was permitted. At the request of the Swiss government the case was subsequently referred to the Grand Chamber of the ECtHR. After the Swiss government informed the Court that the applicant had died, the Grand Chamber declared, by a majority, the application inadmissible. According to the Grand Chamber the applicant had intended to mislead the ECtHR on a matter concerning the very core of her complaint. As a result of this judgment, the findings of the judgment of the Chamber are no longer legally valid.

Another end-of-life judgment concerns the case of Koch v. Germany. ${ }^{26}$ Like in the two earlier mentioned Swiss cases, this application concerned a request for access to a lethal dose of a drug that would have allowed the applicant's wife, who was suffering from complete quadriplegia, to commit suicide at her home address in Germany. Since the request was denied, and the domestic courts dismissed the appeal, the applicant and his wife both went to Switzerland, where the wife of the applicant committed suicide with the help of a Swiss association. Upon return to Germany the applicant brought an action to obtain a declaration that the decisions of the Federal Institute for Pharmaceutical and Medical Products, denying access to a lethal dose of a drug, had been unlawful. These efforts where however declared inadmissible by the competent domestic court. The applicant complained in particular before the ECtHR that the domestic courts' refusal to examine the merits of his complaint had infringed his right to respect for private and family life, as protected by Article 8 ECHR. The ECtHR ruled, having regard to the exceptionally close relationship between the applicant and his wife, and to his immediate involvement in the fulfilment of her wish to end her life, that the applicant could claim to have been directly affected by the refusal of the Federal Institute for Pharmaceutical and Medical Products to grant his wife authorisation to acquire a lethal dose of the medication. The ECtHR found that there had been a violation of the applicant's procedural rights under Article 8 ECHR, in respect of the German courts' refusal to examine the merits of his complaint.

Different from the above mentioned cases, the case Lambert $v$. France concerned a number of applicants who disagreed with a judgment of the French Conseil d'État. They contested the decision of the Conseil d'État to declare lawful the decision taken by the doctor treating Vincent Lambert, their tetraplegic relative, to discontinue his

${ }^{25}$ Gross v. Switzerland, no. 67810/10, 14 May 2013, ECLI:CE:ECHR:2013:0514JUD006781010 and Gross t. Switzerland (GC), no. 67810/10, 30 September 2014, ECLI:CE:ECHR:2014:0930JUD 006781010 .

${ }^{26}$ Koch v. Germany, no. 497/09, 19 July 2012, ECLI:CE:ECHR:2012:0719JUD000049709. 
artificial nutrition and hydration. ${ }^{27}$ The applicants submitted in particular that withdrawing his artificial nutrition and hydration would be contrary to the Member State's obligations under Article 2 ECHR. The Grand Chamber of the ECtHR held that there would be no violation of Article 2 ECHR when the judgment of the Conseil d'État would be implemented. The ECtHR observed in particular that there was no consensus among the Member States of the Council of Europe on the issue of permitting the withdrawal of life sustaining treatment. The ECtHR considered that the provisions of the applicable French act, as interpreted by the Conseil d'Etat, constituted a legal framework which was sufficiently clear to regulate with precision the decisions taken by doctors in situations such as that in the present case. The ECtHR also noted that the present case had been the subject of an in-depth examination in the course of which all points of view could be expressed and that all aspects had been carefully considered. The ECtHR therefore held that Article 2 ECtHR had not been violated, despite the fact - and different to the cases of Pretty, Haas and Gross - there was no request from the person concerned.

Since the case of Lambert, the ECtHR decided on three other cases concerning the withdrawal of life sustaining treatment to minor patients. The case of Charlie Gard $v$. the $U K$ concerned a baby suffering from a rare and fatal genetic disease. ${ }^{28}$ The hospital where Charlie was treated sought a declaration from the domestic courts as to whether it would be lawful to withdraw artificial ventilation and provide Charlie with palliative care. The parents of Charlie were strongly opposed to such a decision and asked the courts to consider whether it would be in the best interests of their son to undergo experimental treatment in the United States of America. The domestic courts decided that it would indeed be lawful for the treating hospital to withdraw life sustaining treatment given the likelihood that Charlie would suffer significant harm if his present suffering was prolonged without any realistic prospect of improvement. According to the domestic courts, the experimental therapy would be of no effective benefit. The parents argued before the ECtHR that the hospital had blocked access to life sustaining treatment for Charlie, and that there had thus been a violation of Article 2 ECHR. They also argued that there had been other violations of the ECHR, indirectly related to the end-of-life decision taken by the domestic court.

A majority of the ECtHR decided to endorse the approach by the domestic courts, and subsequently declared the application of the parents inadmissible. The ECtHR emphasised the wide margin of appreciation of the national authorities when it comes to regulating access to experimental treatment for terminally ill persons and in cases raising sensitive moral and ethical issues. Taking into account these factors, the ECtHR noted that a domestic legal framework, compatible with the ECHR, governing both access to experimental medication as well as the withdrawal of life sustaining treatment was available. The decisions of the domestic courts, according to the ECtHR, also met all the requirements applying to the sensitive issues raised by this case. There was therefore no indication to believe that there had been a violation of Article 2 ECHR.

${ }^{27}$ Lambert et all v. France (GC), no. 46043/14, 5 June 2015, ECLI:CE:ECHR:2015:0605JUD004604314.

${ }^{28}$ Gard et all v. the UK (dec.), no. 39793/17, 28 June 2017, ECLI:CE:ECHR:2017:0627DEC003979317. 
The decisions of the ECtHR in the cases of Afiri and Biddarri v. France ${ }^{29}$ and of Haastrup v. the $U K^{30}$ resembled the decision of the ECtHR in the case Charlie Gard. Both cases concerned the decision to withdraw the life sustaining treatment to minor patients with no realistic life perspectives. The parents of both patients contested the decision to terminate further treatment and turned to the ECtHR.

In the case of Afiri and Biddarri the ECtHR found that the French legislative framework complied with Article 2 ECtHR and that, despite the fact that the parents disagreed with the outcome of the process to take a decision on further treatment, the decision-making process satisfied the requirements of Article 2 ECHR. The ECtHR also decided that French law had provided for a judicial remedy that satisfied the requirements of Article 2 ECHR. The ECtHR therefore declared the application inadmissible.

Whereas the patient in Afiri and Biddarri concerned a 14-year-old daughter in a vegetative state, the patient in Haastrup was a son who had just turned one year. Since his birth, Isaiah Haastrup had been on hospital life-support. The father of Isaiah tried to prevent the hospital to withdraw the ventilation from his son. After the ECtHR had all the material on this case in its possession, the ECtHR found that they did not disclose any appearance of a violation of the rights and freedoms set out in the ECHR and declared the application inadmissible.

\section{Analysis and conclusions}

Since 2002 the ECtHR has taken a number of judgments and decisions on end-of-life issues. The ECtHR first stipulated, in the case of Pretty $v$. the $U K,{ }^{31}$ that the right to life, as protected by Article 2 ECHR, did not entail a right to die. In later judgments and decisions the ECtHR allowed for exceptions to be made on the right to life. These exceptions are based on the well informed wishes expressed by mentally competent patients, making use of their right to private life, as protected by Article 8 ECHR. So far, these wishes can both relate to the decision not to be treated or the wish to have access to a lethal dose of a drug. The ECtHR allows Member States a large margin of appreciation to regulate these issues, also to ensure that these exceptions are not incompatible with Article 2 ECHR.

There have also been a few judgments and decisions in which relatives contested the decision of domestic courts to discontinue the artificial nutrition, hydration or other form of life sustaining treatment of a patients. In these judgments and decisions the ECtHR emphasises the importance of a good and foreseeable decision-making process where all arguments expressed are taken into account. Also with respect to these cases, the ECtHR bestows a large margin of appreciation on Member States.

So far the ECtHR had not the opportunity to review the legality of euthanasiathat is to say, the deliberate ending of the life of a patient on his or her request with the

\footnotetext{
${ }^{29}$ Afiri and Biddarri v. France (dec.), no. 1828/18, 23 January 2018, ECLI:CE:ECHR:2018:0123DEC 000182818.

${ }^{30}$ Haastrup v. the UK (dec.), no. 9865/18, 6 March 2018.

${ }^{31}$ Pretty v. the UK, no. 2346/02, 29 April 2002, ECLI:CE:ECHR:2002:0429JUD000234602.
} 
assistance of a physician - or other forms of physician assisted dying. Therefore, we do not know how the ECtHR is going to decide on such cases when presented to the ECtHR. Given the large margin of appreciation which the ECtHR commonly allows States when it comes to end-of-life and other sensitive moral and ethical issues on which there is no consensus amongst the Member States of the Council of Europe, ${ }^{32}$ it is not to be expected that the ECtHR will radically prohibit such domestic laws and policies, provided that they are compatible with Article 2 ECHR, only apply to mentally competent persons and are based on the principle of informed consent.

Despite the fact that the Biomedicine Convention was adopted in 1987, emphasising the importance of-amongst others-individual consent, in none of the above mentioned cases any reference to this Convention was made. Admittedly, Germany and the UK are not parties to the Biomedicine Convention. However, France and Switzerland had ratified this Convention and quite some end-of-life cases emerged from these two countries. There is no clear explanation for the absence of references to the Convention. It can only be concluded that the ECtHR is so far able to judge on end-of-life cases presented to it on the basis of the 1950 ECHR, and not in need to explicitly refer to the Biomedicine Convention. This shows again that the ECHR is a living instrument that should be interpreted in the light of the present-day conditions. ${ }^{33}$ This may only change when a protocol on end-of-life issues is adopted to complement the Biomedicine Convention, but there are no plans to do so in the near future.

Open Access This article is distributed under the terms of the Creative Commons Attribution 4.0 International License (http://creativecommons.org/licenses/by/4.0/), which permits unrestricted use, distribution, and reproduction in any medium, provided you give appropriate credit to the original author(s) and the source, provide a link to the Creative Commons license, and indicate if changes were made.

\section{References}

1. Negri, S.: Ending life and death. In: den Exter, A. (ed.) European Health Law, pp. 219-241. Maklu, Antwerp (2017)

\footnotetext{
${ }^{32}$ Evans v. the UK (GC), no. 6339/05, 10 April 2007, ECLI:CE:ECHR:2007:0410JUD000633905, para. 59.

${ }^{33}$ Tyrer v. the UK, no. 5856/72, 25 April 1978, ECLI:CE:ECHR:1978:0425JUD000585672, para. 31.
} 